
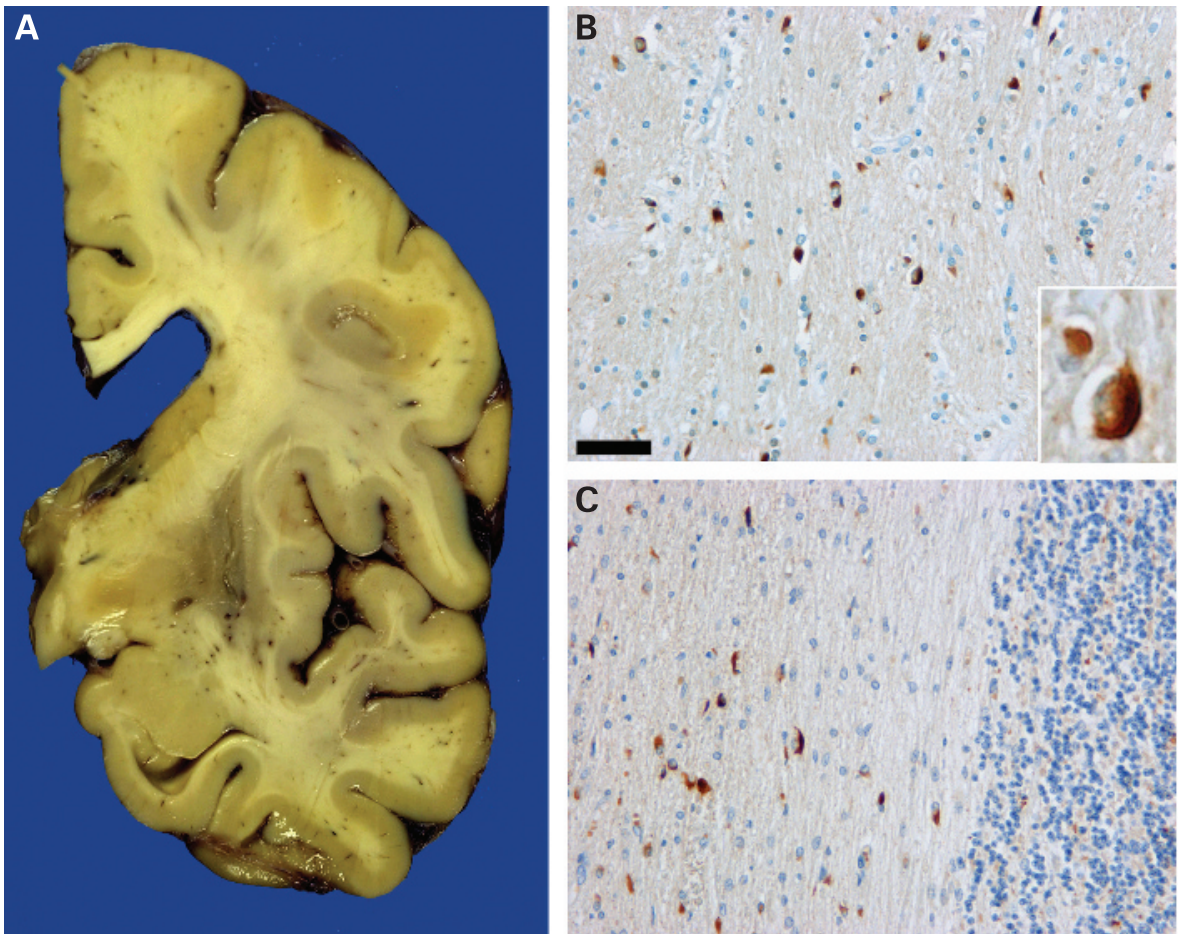

\title{
Definite multiple system atrophy in a German family
}

Multiple system atrophy (MSA) is a presumed sporadic neurodegenerative disorder of unknown aetiology, clinically characterised by poorly levodopa responsive parkinsonism and/or cerebellar dysfunction in combination with autonomic failure. ${ }^{1} \mathrm{We}$ previously identified a family with a typical MSA phenotype in two successive generations. ${ }^{2}$ One affected patient of that pedigree, now deceased at age 82 , and postmortem examination of the brain revealed findings typical of definite MSA. ${ }^{3}$ Severe atrophy of the putamen (fig 1A) and depigmentation of the substantia nigra and pontine and cerebellar atrophy were found upon macroscopic inspection. Formalin-fixed, paraffin embedded sections stained with haematoxylin/eosin showed profound neuronal loss

Figure 1 Gross and microscopic findings in familial multiple system atrophy. (A) Atrophy and brownish discoloration of the putamen. Immunostaining for $\alpha$-synuclein revealed numerous glial cytoplasmic inclusions in putamen (B) and cerebellar white matter (C). The insert in (B) shows a higher magnification of the inclusions. Scale bar, $50 \mu \mathrm{m}$ in (B) and (C) and $12.5 \mu \mathrm{m}$ in the insert in (B). 
and gliosis in the striatum, globus pallidus, substantia nigra pars compacta, pontine nuclei and inferior olivary nuclei, marked Purkinje-cell loss and demyelination of cerebellar white matter. Immunohistochemistry for $\alpha$-synuclein (SNCA) revealed widespread glial cytoplasmic inclusions (GCIs) most numerous in the basal ganglia (fig 1B), cerebellar white matter (fig 1C), brainstem and spinal cord, and moderate numbers of GCIs in the frontal white matter and corpus callosum. Only mild Alzheimerrelated pathology with single tau-positive neurofibrillar tangles and neuropil threads in the entorhinal and transentorhinal cortex was detectable, and immunohistochemistry with an antibody against TDP-43 was negative (not shown). Sequencing of the entire coding region of the $\alpha$-synuclein gene revealed no mutation; further, quantitative PCR of exon 3 and exon 4 showed no increased SNCA dosage (data not shown).

Genetic testing had excluded spinocerebellar ataxia (SCA) types 1-3, 6, 7 and 17 in the presented family. In line with previously published data, we also found no mutation in the SCNA gene or a gene dosage effect in the deceased patient. ${ }^{45}$ Our findings suggest that the present diagnostic criteria for MSA, which explicitly exclude patients with "a family history of a similar disorder," might have led to an underestimation of familial MSA cases. ${ }^{1}$ It may be prudent to take into account the possibility of a hereditary component in MSA and to search for more families along the quest to resolve the aetiology of MSA. Similar to Parkinson disease, genetic analysis of larger families might provide clues to the aetiology of this devastating disease.

\footnotetext{
U Wüllner, ${ }^{1}$ I Schmitt, ${ }^{1}$ M Kammal, ${ }^{2}$ H A Kretzschmar, ${ }^{3}$ M Neumann ${ }^{3}$
}

${ }^{1}$ Department of Neurology, University Bonn, Bonn, Germany; ${ }^{2}$ Department of Legal Medicine, University Medical Centre Hamburg-Eppendorf, Hamburg, Germany; ${ }^{3}$ Center for Neuropathology and Prion Research, Ludwig-Maximilians University, Munich, Germany

Correspondence to: $\mathrm{Dr} U$ Wüllner, Department of Neurology, University Bonn, Sigmund Freud Str. 25, D-53105 Bonn, Germany; wuellner@uni-bonn.de

Funding: This study was supported by the Kompetenznetz Parkinson (01G19901), NGFN (01GS0115, NV-SO2T9), the BONFOR Program of the University Bonn the German Brain Bank (01GI0505) and the "Deutsche Parkinson Vereinigung."

Competing interests: None.

Patient consent: Obtained.

Received 22 July 2008

Revised 26 August 2008

Accepted 23 September 2008

J Neurol Neurosurg Psychiatry 2009;80:449-450.

doi:10.1136/jnnp.2008.158949

\section{REFERENCES}

1. Gilman S, Low PA, Quinn $\mathrm{N}$, et al. Consensus statement on the diagnosis of multiple system atrophy. J Auton Nerv Syst 1998;74:189-92.

2. Wüllner U, Abele M, Schmitz-Hübsch T, et al. Multiple system atrophy in a German family. $J$ Neurol Neurosurg Psych 2004;75:924-5.
3. Trojanowski J0, Revesz T. Proposed neuropathological criteria for the post mortem diagnosis of multiple system atrophy. Neuropathol Appl Neurobiol 2007;33:615-20.

4. Ozawa T, Takano H, Onodera 0 , et al. No mutation in the entire coding region of the alpha-synuclein gene in pathologically confirmed cases of multiple system atrophy. Neurosci Lett 1999;270:110-12.

5. Fuchs J, Nilsson C, Kachergus J, et al. Phenotypic variation in a large Swedish pedigree due to SNCA duplication and triplication. Neurology 2007;68:91622. 


\section{JNNP}

\section{Definite multiple system atrophy in a German family}

U Wüllner, I Schmitt, M Kammal, et al.

J Neurol Neurosurg Psychiatry 2009 80: 449-450

doi: 10.1136/jnnp.2008.158949

Updated information and services can be found at:

http://jnnp.bmj.com/content/80/4/449.full.html

\section{These include:}

References This article cites 5 articles, 2 of which can be accessed free at: http://jnnp.bmj.com/content/80/4/449.full.html\#ref-list-1

Email alerting Receive free email alerts when new articles cite this article. Sign up in service the box at the top right corner of the online article.

Notes

To request permissions go to:

http://group.bmj.com/group/rights-licensing/permissions

To order reprints go to:

http://journals.bmj.com/cgi/reprintform

To subscribe to BMJ go to:

http://group.bmj.com/subscribe/ 